\title{
POLITICAL, ECONOMIC, AND CULTURAL COOPERATION BETWEEN THE REPUBLIC OF BELARUS AND THE WESTERN BALKAN THROUGH THE LENS OF RELATIONS WITH SERBIA
}

\begin{abstract}
Asja Pentegova ${ }^{1}$
Abstract: The multi-vector foreign policy of the Belarusian state provides opportunities for collaboration and platforms for dialogue and cooperation with all countries of the Western Balkans. Serbia is the most promising Balkan country for Belarus in terms of communication and cooperation. Serbia is in many ways similar to Belarus in its creative attempts to manoeuvre between the centres of power to maximize the protection of its national interests.

Belarusian-Serbian relations have been and are stable. They show relatively high dynamics of economic contacts and a developed legal framework. Both Belarus and Serbia implement economic policies based on developing trade relations as well as on supporting the establishment of joint ventures and promoting investment cooperation.

Belarus and Serbia are roughly equal regional actors. Among the key areas of cooperation, the crucial role of joint emergency prevention and response efforts and, in particular, joint crisis management exercises should be highlighted. The Belarusian and Serbian military, jointly with their Russian counterparts, have been organising the Slavic Brotherhood Military Exercises since 2016.

Cooperation between Belarus and Serbia also includes interaction in the spiritual and cultural sphere. Sharing common spiritual and cultural values is one of the leading factors in the formation of close relations between the two countries. To enhance cooperation in all sectors, Belarus and Serbia should consider the inclusion of tourism in the promising areas of bilateral
\end{abstract}

\footnotetext{
${ }^{1}$ Advisor, Belarusian Institute for Strategic Researches, Minsk, Belarus. E-mail: pentegova@bisr.by.
} 
relations. The development of relations between Serbia and Belarus contributes not only to the preservation of spiritual and cultural ties but also to the unity of all Slavic peoples.

Keywords: Belarus, Serbia, bilateral relations, foreign policy, economic contacts, culture cooperation, fraternal support.

\section{Political, economic, and cultural cooperation between the Republic of Belarus and the Western Balkans through the lens of relations with Serbia}

The multi-vector foreign policy of the Belarusian state provides opportunities for collaboration and platforms for dialogue and cooperation with all countries of the Western Balkans.

The relations between Belarus and Serbia have a long history, and its high point must be the political decision of the President of Belarus to support Serbia and visit Belgrade during the NATO bombing of the Serbian capital in April 1999. This instilled hope and confidence in the Yugoslav population. Belarus is perceived in Serbia as a symbol of virtue. It was not able to counter the NATO forces, but its "fraternal support" was much appreciated.

Based on the classification developed by Mark Khrustalev, a prominent Russian professor (MGIMO University of the Ministry for Foreign Affairs of the Russian Federation), three key vectors shaping the political and psychological aspects of relations between countries can be distinguished in the most general terms. ${ }^{2}$

"Friend-Enemy Vector": is characterised by the highest degree of tension in the relationship as opposed to "fraternal relations" considered as the ultimate degree of friendliness. For example, the rivalry mode relations developed during the Cold War between Russia and the United States.

"Dependence-Independence" Vector: is based on the "balance of forces" between countries, or rather, on the obvious superiority of one international actor over another, where the second actor is explicitly dependent, both politically and economically, on the leading state. For example, the relations

\footnotetext{
${ }^{2}$ Khrustalev. M.A. (2008). Analysis of International Situations and Political Expertise. Moscow, Regional Library of International Relations.
} 
within Belarus-Russia Union State, as well as within the EAEU, where Russia is a clear leader.

"Trust-Distrust" Vector: it emerges as a consequence of the conventionality of the policy as well as its moral and ethical changes in compliance with treaties, agreements, conventions, and agreements reached.

It is obvious that the relations between Belarus and Serbia belong to this vector, in which there is no obvious superiority of any of the two actors. The countries are in equal bilateral economic and political relations that meet the needs and interests of both countries and do not have obvious pressure on the political course of the other country. It should be noted that the more favourable the political and psychological climate, the fewer obstacles there will be for interaction between countries in all spheres - politics, economy, culture, etc.

The political contacts between the countries have noticeably intensified in recent years: Tomislav Nikolić visited Minsk at the beginning and the end of his presidential term; Aleksandar Vučić, President of Serbia, visited the 2nd European Games held in Minsk in June 2019; Alexander Lukashenko paid an official visit to Belgrade in December 2019.

Implementing a consistent approach, Minsk has proved to be an important political partner of Belgrade. The "Kosovo issue" is a special case in relations between the two countries. Belarus' position with regard to the unilateral declaration of independence of Kosovo is clear: on all international fora, Minsk supports the territorial integrity of Serbia.

Belarusian-Serbian relations have been and are stable. They show relatively high dynamics of economic contacts and a developed legal framework.

The existing legal framework of Belarusian-Serbian relations can be formally divided into four main categories:

- Cooperation agreements;

- Foreign relations (documents);

- Trade and economic relations (documents);

- Scientific, cultural, and humanitarian cooperation (documents).

In June 2015, during the official visit to Minsk of Maja Gojković, Chair of the Serbian Parliament, the Memorandum on Cooperation between the National Assembly of the Republic of Belarus and the National Assembly of the Republic of Serbia was signed. 
The interregional contacts between Belarus and Serbia are supported by cooperation agreements signed by a number of Belarusian and Serbian cities.

In 2016, Minsk hosted Belgrade Days, and in 2017, Minsk days held in Belgrade were aimed at promoting the cultures of the two peoples as well as trade and economic contacts and tourism.

Serbia is the most promising Balkan country for Belarus in terms of communication and cooperation. The history of Belarus-Serbia relations does not contain any encumbrances, except for Belgrade's solidarity with European sanctions. Serbia is in many ways similar to Belarus in its creative attempts to manoeuvre between the centres of power to maximize the protection of its national interests.

A gradual increase in trade between Belarus and Serbia was made possible by the bilateral free trade agreement (2009), which abolishes import customs duties and fees save in respect of a special commodity group, which is an exception to free trade as specified in the 2011 bilateral protocol.

The trade turnover proved particularly dynamic in the first few years after the signing of the FTA agreement, while it has stagnated in the last five years.

In 2009, the trade turnover between Belarus and Serbia amounted to USD 53.5 million. One year later, it totalled USD 116.5 million (a more than twofold increase). In 2011 it was USD 145.4 million and in 2012 nearly USD 150 million. $^{3}$

At the same time, the Belarus-Serbia cooperation roadmap for 2017-2018 set a goal to increase trade turnover by USD 500 million. However, the mutual trade turnover which totalled USD 240 million at the best of times, in 2018 amounted to USD 148 million, falling by 38.2\% compared to 2017 (the rate of decline in Belarusian exports was $40.9 \%$ - up to USD 84.5 million).

In particular, one of the obstacles for the economic cooperation between Belarus and Serbia is the geographic distance (absence of common borders), which increases supply chain and transportation costs and, consequently, the cost of inter-country trade.

In addition, it is important to understand despite the positive personal attitude of the President Vučić to Belarus, the cooperation with Minsk is

\footnotetext{
${ }^{3}$ Belarus-Serbia: prospects for cooperation (2016, November 11), retrieved from http://www.mintorg.gov.by/index.php?option=com_content\&task=vie w\&id=1720\& Itemid=30. Accessed 25 July 2020.
} 
viewed in the broader context of cooperation with the Russian Federation and the post-Soviet countries.

The signing of the FTA agreement between Serbia and the EAEU in October 2019 indicates the potential for an increase in mutual trade. The Serbian society sees the Eurasian Economic Union as a project to establish a new supranational pole of power destined to become a link between Europe and the Asia-Pacific region, and which has a deep geopolitical basis for uniting Central Eurasia.

The implementation of this Agreement is also important for strengthening the positions of the EAEU member states, in particular, Belarus, in the markets of the Western Balkans.

Both Belarus and Serbia implement economic policies based on developing trade relations as well as on the support of emerging joint ventures and investment cooperation.

Joint production on the Serbian territory is attractive to Belarus because the existing Central European Free Trade Agreement (CEFTA) establishes a free trade regime between the member states. Taking into account the level of Belarus-Serbia trade and investment cooperation, there is a potential for Belarus to enter foreign markets of the Balkan countries. Since the signing of the Additional Protocol in 2011, the CEFTA countries have abolished all customs duties on imports, equivalent measures, and all import duties of a fiscal nature in mutual trade.

The CEFTA countries (Albania, Bosnia and Herzegovina, North Macedonia, Moldova, and Montenegro) are the second-largest trade partner of Serbia, ensuring an annual surplus of about USD 2 million and a 15\% share in the country's total trade.

Serbia has a law on foreign investment that guarantees the same legal status for domestic and foreign investors, i.e., freedom of investment, national security, legal security, and the ability to transfer profits abroad. These guarantees for Belarusian investors create a good investment climate.

Serbia's interest in such projects is motivated by the fact that over the previous two decades, during the transition to a free-market economy, Serbia has almost lost its primary manufacturing sector. Given the need for reindustrialisation, foreign direct investment is an important tool for reviving the economy, improving its competitive qualities, facilitating access to international trade markets, and improving the balance of payments. 
It is to be understood, however, that since the European vector of Serbia's development is considered a priority, the trade and economic cooperation between Serbia and Belarus, as well as between Serbia and other EAEU countries, is limited to areas that either do not raise concerns with the European Union or are largely determined by the EU.

Belarus and Serbia are roughly equal regional actors. Neither of the two countries dominates in trade and economic cooperation, unlike, for example, Russia-Belarus relations.

Among the key areas of cooperation the crucial role of joint emergency prevention and response efforts, and, in particular, joint crisis management exercises should be highlighted. The Belarusian and Serbian military, jointly with their Russian counterparts, have been organising the Slavic Brotherhood Military Exercises since 2016. These exercises have become the sequel of successful cooperation between the Russian airborne troops and the special brigade of the Serbian army, which started with "SREM2014" held on the territory of the "Nikinca" training ground in Vojvodina and was aimed at training anti-terrorist special units. ${ }^{4}$ According to the Minister of Defence Alexander Vulin, the Republic of Serbia attaches great importance to military and technical cooperation, which certainly sets out the vector for the development of future relations between the countries.

It is obvious that military and technical cooperation between Serbia and Belarus is developing, but it is not strategically oriented. Regrettably, Serbia's cooperation with NATO and the United States in the framework of the Partnership for Peace, Status of forces Agreement (SOFA), and Individual partnership action plan (IPAP) is incomparably more intense, although Serbia claims military neutrality.

After Montenegro signed the accession treaty to join NATO, the parity of Alliance forces in the Balkans has strengthened due to the overall expansion of its member states. The Agreement signed in September 2015 between the Government of the Republic of Serbia and the NATO Support and Procurement Organization (NSPO) on cooperation in the field of logistics support gained public attention only after its ratification by the President of Serbia in February 2016. It commits Belgrade to grant the NSPO

\footnotetext{
${ }^{4}$ Serbia summed up the results of the joint military exercises SREM 2014 (2014, November 15), retrieved from https://function.mil.ru/news_page/country/more. htm?id=12000000@egNews. Accessed 15 July 2020.
} 
personnel freedom of movement in the country (article 10, paragraph 2), access to public and private facilities (article 11, paragraph 1), diplomatic immunity under the Vienna Convention (article 10, paragraph 1), and to exempt the property of the Alliance and its representatives from customs duties and taxes (article 10, paragraphs 4 and 5). ${ }^{5}$

Serbia is surrounded by NATO and EU member states. Even though the official policy aimed at European integration has been undisputed for years and perceived positively by both public institutions and people, the situation regarding the prospect of NATO membership is exactly the opposite: Serbia has no desire to become a member of NATO, it intends to maintain its independence. The state supports and equips its army. In particular, since 2013 the Serbian Parliament has the observer status at the CSTO Parliamentary Assembly - a kind of counterweight to NATO.

Cooperation between the defence industry enterprises of Belarus and Serbia has developed consistently. For example, in 2018, Belarus handed over $4 \mathrm{MiG}-29$ aircraft to Serbia as part of military and technical assistance. In early 2021, Belarus will repair and upgrade them.

The prompt response to a request for humanitarian aid during a natural disaster demonstrates that partnership relations still prevail over pragmatism in decision-making. As an example, the response to the flood in Serbia in 2014 should be mentioned. International rescue teams from Belarus and 11 other countries arrived in Serbia on short notice.

Humanitarian cooperation suffers from political controversy to a lesser degree. Since early 2020, the fight against the coronavirus pandemic has clearly shown and proved the strength of bilateral relations between small and medium-sized countries in times of crisis and an adverse epidemiological situation, when, regardless of their economic power they help each other. Political elites find ways to cooperate and help friendly nations when it comes to rescuing people in danger. The Belarusian flight crew transported humanitarian aid from China for the Serbian population. Subsequently, the Serbian Government sent two planes with medical supplies as humanitarian aid to Belarus.

\footnotetext{
${ }^{5}$ How Serbia balances between NATO and Russia (2016, April 19), https://expert.ru/ 2016/04/19/assimetrichnaya-nejtralnost-kak-serbiya-balansiruet-mezhdu-nato-irossiej/. Accessed 11 July 2020.
} 
Thus, along with the economy and politics, humanitarian and cultural cooperation provides positive examples of relations between Belarus and Serbia.

Bilateral cooperation in the field of culture is developing based on the intergovernmental agreement on cooperation and the interdepartmental cooperation programme signed in 2012.

Cultural cooperation based on a common ideological and symbolic space and a common historical memory resists the falsification of history and is an essential element of close relations between countries.

Cooperation between Belarus and Serbia also includes interaction in the spiritual and cultural sphere. The Orthodox Church plays an important role in both Belarusian and Serbian society, and it can be safely said that Orthodox values serve as a unifying framework for Belarus and Serbia. Civilizational identity can be considered as one of the factors uniting two peoples. Sharing common spiritual and cultural values is one of the leading factors in the formation of close relations between the two countries.

The development of spiritual and cultural ties between Serbia and Belarus helps the "Christian world" to balance the influence of cultural "ultra-liberalism", which can overnight involve the Muslim peoples of the region into the Middle East extremism.

According to Konstantin Kosachev, only those who are able to use all available resources (language, education, tourism, national cuisine, cinema, brands) make significant progress in international fora. ${ }^{6}$

In 2017, the Agreement between the Government of the Republic of Belarus and the Government of the Republic of Serbia on cooperation in the field of tourism was signed. ${ }^{7}$

To enhance cooperation in all sectors, Belarus and Serbia should consider the inclusion of tourism in the promising areas of bilateral relations. The growing importance of tourism is an essential component of

\footnotetext{
${ }^{6}$ Kosachev, K.I. (2012). Conversation with Konstantin Kosachev: Russia maintains its authority in the world [Audio], retrieved from http://rus.ruvr.ru/radio_broadcast/ 65446337/86815347.html. Accessed 01 July 2020.

${ }^{7}$ Embassy of the Republic of Belarus in the Republic of Serbia: cultural cooperation (2018, December 1), http://serbia.mfa.gov.by/ru/bilateral_relations/cultural/eea12 60d7e5b1a69.html. Accessed 21 June 2020.
} 
the attractive image of "fraternal partnership". The promotion of historical and cultural heritage sites, as well as spiritual shrines of the Orthodox world (for example, integrated into combined tour itineraries), can ensure an increase in tourist flows between the two countries. The Agreement between the Government of the Republic of Belarus and the Federal Government of the Federal Republic of Yugoslavia on the abolition of visas (2009) applies in the relations between Belarus and Serbia. The current visa-free 30-day regime helps attract tourists, ensuring the unhindered movement of persons. In the era of globalisation, "territory brands" have become fundamental trademarks of the tourism industry. ${ }^{8}$ Both Serbian and Belarusian lands are notable for their national cuisines and hospitality, and also for agritourism, which remains an undervalued resource.

Academic cooperation is essential for both countries. A number of Serbian faculties are accredited in European countries, while Belarus has a well-developed scientific capacity: state universities offer great opportunities and ensure a high standard of knowledge. This is one of the reasons why it is important to cooperate in the scientific and educational spheres, although competitive programmes should be developed.

The universities of the two countries should support student and academic exchange projects based both on bilateral agreements and international education programmes. It should be understood and taken into consideration that the prospects for such cooperation are often limited due to the lack of interest among young people who prefer renowned European universities. The development of competitive programmes providing for certain advantages and greatest incentives possible as well as scholarships to students would attract promising young people to projects that are less visible compared to Western ones.

The development of relations between Serbia and Belarus contributes not only to the preservation of spiritual and cultural ties but also to the unity of all Slavic peoples. Fraternal relations are an important part of the partnership, but they are merely a foundation for the strengthening of political and economic ties, which must first and foremost be based on mutually beneficial agreements that should be tailored to each country's

${ }^{8}$ Cherevichko, T.V. (2014). Tourism as a tool of public diplomacy. Journal "Izvestiya of Saratov University. New Series. Series: History. International Relations”, (14), pp. 93-95. 
and the Western Balkan region's specific conditions and take into account certain unresolved territorial issues.

\section{References}

Khrustalev. M.A. (2008). Analysis of International Situations and Political Expertise. Moscow, Regional Library of International Relations.

Belarus-Serbia: prospects for cooperation (2016, November 11), retrieved from http://www.mintorg.gov.by/index.php?option=com_content\&task $=$ vie $\mathrm{w} \& \mathrm{id}=1720 \&$ Itemid=30. Accessed 25 July 2020.

Serbia summed up the results of the joint military exercises SREM 2014 (2014, November 15), retrieved from https://function.mil.ru/news_ page/country/more.htm?id=12000000@egNews. Accessed 15 July 2020.

How Serbia balances between NATO and Russia (2016, April 19), https://expert.ru/2016/04/19/assimetrichnaya-nejtralnost-kakserbiya-balansiruet-mezhdu-nato-i-rossiej/. Accessed 11 July 2020.

Kosachev, K.I. (2012). Conversation with Konstantin Kosachev: Russia maintains its authority in the world [Audio], retrieved from http://rus. ruvr.ru/radio_broadcast/65446337/86815347.html. Accessed 01 July 2020.

Embassy of the Republic of Belarus in the Republic of Serbia: cultural cooperation (2018, December 1), http://serbia.mfa.gov.by/ru/bilateral_ relations/cultural/eea1260d7e5b1a69.html. Accessed 21 June 2020.

Cherevichko, T.V. (2014). Tourism as a tool of public diplomacy. Journal "Izvestiya of Saratov University. New Series. Series: History. International Relations", (14), pp. 93-95. 